Gladys De La Cruz, Florida International University: "Racial Identification and Its Effects on Attitudes towards Domestic Policy"

Angelique Douyon, The College of New Jersey: "Marching Towards a Homeland of the Free: Perceptions of Discrimination and Black Political Participation"

Tehama Lopez, University of Virginia: "A Look at the Death Penalty and Race: A Statistical Analysis of Black and White Attitudes"

Michelle Oby, Marquette University: "Feminism and Affirmative Action"

Itika Oldwine, University of California, Los Angeles: "Racial Composition of Neighborhoods' Affect on Residents' Group Cohesion"

Gabriel Sanchez, St. Mary's University (TX): "United We Stand, Divided We Fall"

Jawad Towns, Louisiana State University: "The Role of Black Media in Galvanizing Black Political Activism and Participation"

Velsa M. Weaver, University of Virginia: "Explaining the Exception: Race-Consciousness, Parties, and Participation of Blacks"

Deva Woodly, University of Virginia: "Theology Matters: Understanding the Role of Ideology in African American Political Participation"

The impressive presentations by the students grew out their final projects for the graduate-level quantitative analysis and race and American politics courses they took during the five-week Institute. While at the Annual Meeting, the students were invited to attend panels and receptions and encouraged to meet scholars within the profession.

The Ralph Bunche Summer Institute is now in its fifteenth year, and continues to introduce undergraduate minority students to the world of graduate study. The Institute's main goal is to encourage more AfricanAmerican, Latina/o, and Native American students to pursue academic careers in political science. To that end, the Institute exposes participants to leading issues and problems in the discipline and profession of political science, introduces students to leading scholars in the field,

\title{
Library of Congress Welcomes APSA Scholars
}

The Library of Congress held an open house and orientation sessions for APSA members in conjunction with the APSA Annual Meeting that attracted scholars interested in learning to effectively use the Library's resources. Organized by Carolyn Brown, acting director of the Area Studies Division, and the APSA Area Studies Liaison Group, the open house allowed APSA members to access the Library's collections using their Annual Meeting badges in lieu of a regular readers' card. The orientation sessions were offered by Paul Baker, a political science specialist in the Humanities and Social Sciences Division, and attracted a number of graduate students and junior scholars. Dr. Baker gave an overview of the Library's holdings, answered questions, and explained how to use many of the online resources including THOMAS, the Library's web tool for researching issues relating to the U.S. Congress. After the orientation session, Prosser Gifford, director of Scholarly Programs, spoke with the group about various ways in which the Library supports the broader academic community.

informs the students of career opportunities for political scientists, and enhances the writing, research, and analytical skills of the students, making them more competitive applicants for graduate school admissions and financial assistance. Also included in the program are Graduate Record Exam preparatory classes and a recruitment fair of graduate programs.

Under the direction of RBSI Director Paula McClain, professor of political science and law at Duke University, students are introduced to the world of political science outside of their own undergraduate institutions. Many students who have attended the program go on to Ph.D. programs in political science with full fellowships and teaching assistantships. Three Bunche alumni have already been named assistant professors at the university level.

To get more information about and application materials for the Ralph Bunche Summer Institute, please visit www.apsanet.org/about/ minoirity.

\section{Graduate Students Attend Meeting with APSA Assistance}

In a continuing effort to assist graduate students wishing to participate in the Annual Meeting, the Association awarded 56 Advanced Graduate Student Grants for its 2000 meeting in Washington, DC. Winners were selected from a pool of over 115 applicants, all of whom were scheduled to present a paper or poster.

Since the grants were first awarded in 1994, almost 200 doctoral students from the United States have been funded. The number of applications submitted for consideration has risen by nearly $50 \%$ since the first year of the program.

As the number of applicants grows and the level of departmental support available to graduate students becomes more limited, the Association finds it increasingly difficult to meet its goal of enabling student participation in the meeting. Contributions to the travel grant fund are welcome from Organized Sections, Related Groups, and individual members. If you are interested in contributing, please contact Sue Davis at 202-483-2512 or sdavis@apsanet.org.

The name and affiliation of the 2000 winners follow.

Fiona B. Adamson, Columbia University Paul Axelrod, University of Washington John Baxter, Old Dominion University

Ben Bishin, University of California, Los Angeles

Khalilah L. Brown, Ohio State University

Rhonda Callaway, University of North Texas

Steven J. Campbell, University of South Carolina

Teri L. Caraway, Northwestern University Miki Caul, University of California, Irvine 
Claudia Dahlerus, University of Colorado, Boulder

Heather Dash, Emory University

Leniece Davis, University of Chicago

Sarah J. Diel-Hunt, Southern Illinois

University

David M. Edelstein, University of Chicago

Christina Ewig, University of North

Carolina, Chapel Hill

Jason A. Frank, Johns Hopkins University

Gregory A. Fugate, University of Colorado, Boulder

Douglas Goodman, University of Utah

Elise Guiliano, University of Chicago

Jacob S. Hacker, Yale University

Michael Hammer, University of Michigan

Allen Hicken, University of California, San Diego

Donna Hoffman, University of Oklahoma

Valerie F. Hunt, University of Washington

Jacques E.C. Hymans, Harvard University

Mark T. Imperial, Indiana University,

Bloomington

Jennifer Jerit, University of Illinois, Urbana-Champaign

Cindy D. Kam, University of Michigan

Patricia Maria Keilbach, University of Oregon

Michael Kenney, University of Florida

Barbara M. King, Southern Illinois University

Sarah Kenyon Lischer, Massachusetts

Institute of Technology

Mary Malone, University of Pittsburgh

Vesna Marcina, University of California, Santa Barbara

Jody L. McMullen, University of Ari-

zona

Bonnie M. Meguid, Harvard University

Anne C. Miers, Rice University

Stephen Mockabee, Ohio State University

Kimberly Morgan, Princeton University Vincent Phillip Munoz, Claremont Graduate School

Thomas J. Nisley, University of Florida Jason L. Pierce, University of Texas, Austin

Lori Poloni-Staudinger, Indiana University, Bloomington

Robert W. Rauchhaus, University of

California, Berkeley

Daniel H. Roberts, Pennsylvania State University

Scott Robinson, Texas A\&M University

Thomas J. Rudolph, University of Minnesota

David Schecter, University of Florida

Ethan Scheiner, Duke University

Keesha Middlemass Scott, University of Georgia

Jennifer C. Seely, Washington University Evelyn Simien, Purdue University
Verity Smith, University of California, San Diego

Alexander Thompson, University of Chicago

Jaroslav Tir, University of Illinois, Ur-

bana-Campaign

Hans von Rautenfeld, University of

South Carolina

McGee Young, Syracuse University

\section{An International Annual Meeting}

As the APSA Annual Meeting becomes increasingly international in nature, the Association has increased its financial support to international scholars and students wishing to attend. Over the past five years, APSA has assisted hundreds of scholars through a combination of travel support, hotel accommodations, and complimentary meeting registrations.

This past year, the travel grant program received record high number of applications and APSA awarded $\$ 13,000$ to international scholars. The grantees represented 23 countries and came from 52 institutions worldwide.

For more information on APSA's travel grant program, please visit our web site (www.apsanet.org/about/ international/travel.cfm).

The names and affiliations of the 2000 winners follow.

Advanced International Graduate Student Travel Grant Program

Jungug Choi, University of Texas, Austin

Javier A. Couso, University of California, Berkeley

Frieda Fuchs, Harvard University

Thomas Gschwend, University at Stony

Brook, SUNY

Manjusta Gupte, Purdue University

Parakh N. Hoon, University of Florida Yusaku Horiuchi, Massachusetts Institute of Technology

Victoria Tin-bo Hui, Columbia University

Ji Hyang Jang, University of Texas, Austin

Sangbae Kim, Indiana University,

Bloomington

Katrin Kriz, Brandeis University

Bahar Leventoglu, University of Rochester

Dimitri Mitin, Purdue University

Gulenay Ozbek, New York University

Eleonora Pasotti, Columbia University
Grigore Pop-Eleches, University of California, Berkeley

Oxana Shevel, Harvard University

Maria Spirova, University. of Wisconsin, Milwaukee

Triadafilos Triadafilopoulos, New

School for Social Research

Erik Voeten, Princeton University

\section{Senior Scholar Travel Grant Program}

Ruth Abbey, University of Notre Dame Attila Agh, Budapest University of Economics

Karen Anderson, University of Twente Dan Anderson, Queen's University Daphna Canetti, University of Haifa Louise Chappell, University of Sydney Stephen Church, Victoria University Jonathan Davies, University of York Claes de Vreese, University of Amsterdam

Petra A. Dobner, University of Potsdam Stephen Fischer, Katholieke Unversiteit Leuven

Amy L. Fletcher, University of Canterbury

Brigitte Geissel, Technical University of Berlin

Rupert Gordon, University of Toronto

Heike Hagedorn, University of Muenster Lisa Hill, Australian National University Yong-Ki Kim, London School of Economics

Bettina Koch, University of Vechta Miriam Laugesen, University of Melbourne

Mechtild Lauth, Universitat Leipzig William Maloney, University of Aberdeen

Petra Meier, Vrije University

Gagik Melkonyan, Yerevan Institute of Foreign Languages

Peter Meyers, Université de Lille III Abdul Noury, Universite Libre de Bruxelles

Roland Pierik, Tillsburg Univeristy Ingrid Robeyns, Cambridge University Wolfgang Rudig, University of Strathclyde

Uwe Serdult, University of Pittsburgh Ben Seyd, University College of London Abdollah Payrow Shabani, University of Ottowa

Laszlo Vass, Budapest University John von Heyking, University of Lethbridge

Mary Walsh, Queensland University of Technology

Stephen White, University of Glasgow

Maureen Whitebrook, University of

Sheffield

Stefan Wolff, University of Bath

Chung-li Wu, National Chung Cheug

University

Tatyana Zakharova, Academy of Public Service

Chian-Fan Zhang, Nanjing University 